\title{
Cryptosporidium parvum and Cryptosporidium hominis subtypes in crab-eating macaques
}

$\mathrm{Li} \mathrm{Chen}^{1 \dagger}$, Suhui Hu${ }^{2+}$, Wen Jiang ${ }^{1}$, Jianguo Zhao ${ }^{3}, \mathrm{Na} \mathrm{Li}^{2}$, Yaqiong Guo ${ }^{2}$, Chenghong Liao ${ }^{3}$, Qian Han ${ }^{3}$, Yaoyu Feng ${ }^{1,2^{*}}$ and Lihua Xiao ${ }^{2^{*}}$ (D)

\begin{abstract}
Background: Non-human primates are often infected with human-pathogenic Cryptosporidium hominis subtypes, but rarely with Cryptosporidium parvum. In this study, 1452 fecal specimens were collected from farmed crab-eating macaques (Macaca fascicularis) in Hainan, China during the period April 2016 to January 2018. These specimens were analyzed for Cryptosporidium species and subtypes by using PCR and sequence analysis of the 185 rRNA and $60 \mathrm{kDa}$ glycoprotein (gp60) genes, respectively.
\end{abstract}

Results: Altogether, Cryptosporidium was detected using 185 rRNA-based PCR in 132 (9.1\%) sampled animals, with significantly higher prevalence in females $(12.5 \%$ or $75 / 599$ versus $6.1 \%$ or $43 / 706)$, younger animals ( $10.7 \%$ or 118/1102 in monkeys 1-3-years-old versus $4.0 \%$ or $14 / 350$ in those over 3-years-old) and animals with diarrhea (12.6\% or 46/365 versus $7.9 \%$ or 86/1087). Four Cryptosporidium species were identified, namely C. hominis, C. parvum, Cryptosporidium muris and Cryptosporidium ubiquitum in 86, 30, 15 and 1 animal, respectively. The identified C. parvum, C. hominis and C. ubiquitum were further subtyped by using gp60 PCR. Among them, C. parvum belonged to subtypes in two known subtype families, namely IloA14G1 (in 18 animals) and IIdA19G1 (in 2 animals). In contrast, C. hominis mostly belonged to two new subtype families $\mathrm{Im}$ and $\mathrm{In}$, which are genetically related to la and $\mathrm{Id}$, respectively. The $C$. hominis subtypes identified included ImA18 (in 38 animals), InA14 (in six animals), InA26 (in six animals), InA17 (in one animal) and liA17 (in three animals). The C. ubiquitum isolates belonged to subtype family XIId. By subtype, ImA18 and IIOA14G1 were detected in animals with diarrhea whereas the remaining ones were mostly found in asymptomatic animals. Compared with C. parvum and C. muris, higher oocyst shedding intensity was observed in animals infected with C. hominis, especially those infected with the Im subtype family.

Conclusions: Data from the study suggest that crab-eating macaques are infected with diverse C. parvum and C. hominis subtypes. The C. parvum llo subtype family previously seen in rodents in China has apparently expanded its host range.

Keywords: Cryptosporidium, Cryptosporidium parvum, Cryptosporidium hominis, Subtypes, Crab-eating macaques

\footnotetext{
*Correspondence: yyfeng@ecust.edu.cn; |xiao1961@gmail.com

'Li Chen and Suhui Hu contributed equally to this work

${ }^{1}$ State Key Laboratory of Bioreactor Engineering, School of Resource

and Environmental, East China University of Science and Technology,

Shanghai 200237, China

${ }^{2}$ College of Veterinary Medicine, South China Agricultural University,

Guangzhou 510642, China

Full list of author information is available at the end of the article
}

(c) The Author(s) 2019. This article is distributed under the terms of the Creative Commons Attribution 4.0 International License (http://creativecommons.org/licenses/by/4.0/), which permits unrestricted use, distribution, and reproduction in any medium, provided you give appropriate credit to the original author(s) and the source, provide a link to the Creative Commons license, and indicate if changes were made. The Creative Commons Public Domain Dedication waiver (http://creativecommons.org/ publicdomain/zero/1.0/) applies to the data made available in this article, unless otherwise stated. 


\section{Background}

Cryptosporidium is a common gastrointestinal parasite, responsible for diarrhea in humans, non-human primates (NHPs) and ruminants $[1,2]$. In humans, they are transmitted by direct person-to-person or animal-to-person contact, or indirectly through ingestion of contaminated water and food [3]. NHPs are genetically related to humans, thus are widely used as animal models in studies of human diseases. As they are in close contact with humans, laboratory NHPs have been considered potential reservoirs of human-pathogenic Cryptosporidium species [4].

To date, nearly 40 Cryptosporidium species have been established [5]. Among them, Cryptosporidium hominis and Cryptosporidium parvum are common species infecting humans [3]. The former has been identified in NHPs in some studies, most of which included its common human-pathogenic subtype families such as Ia, Ib, Id and Ie. The latter, although having a broader host range than $C$. hominis, has only been occasionally detected in NHPs, mostly by its anthroponotic subtype family IIc $[4,6,7]$. Other species occasionally detected in NHPs include Cryptosporidium muris, C. andersoni, C. ubiquitum, C. meleagridis and C. suis [4, 6-10]. Most of these studies were done with wild or captive animals. Thus far, there have been only two studies of Cryptosporidium spp. in farmed NHPs, which reported a low occurrence of $C$. hominis in crab-eating macaques (Macaca fascicularis) in China $[11,12]$.

To further examine the genetic diversity and public health potential of Cryptosporidium parasites in NHPs, we genotyped and subtyped these pathogens and measured the number of oocysts per gram of feces (OPG) in fecal specimens from crab-eating macaques on a commercial farm in Hainan, China.

\section{Methods}

\section{Specimen collection}

In April 2016, June 2017, October 2017 and January 2018, a total of 1452 fecal specimens were collected from crabeating macaques on a commercial farm in Hainan, China. The farm was awarded accreditation from the International Association for Assessment and Accreditation of Laboratory Animal Care in 2009. More than 20,000 animals were kept at the beginning of the study. On the farm, animals were kept in individual cages $\left(1 \mathrm{~m}^{3}\right)$, with $\sim 30$ cages in one room of $60 \mathrm{~m}^{2}$. The cages were $1 \mathrm{~m}$ above the ground to allow stools to fall onto the floor for easy cleaning. Monkeys could interact with animals in neighboring cages. The rooms were cleaned twice daily. Male and female animals were reared in separate areas. Fresh fruit, commercial diet and clean drinking water were regularly distributed.
By gender, these animals were divided into three categories, namely 706 males, 599 females and 147 animals with missing information on the sex. By age, 1102 were 1-3-year-old monkeys and 350 were $>3$ year-old adult monkeys. Because most animals over 4 years of age were sold for laboratory research, the number of adult monkeys was smaller than young monkeys on the farm. At the sampling, 365 animals had loose stools, as defined by runny fecal consistency, while the remaining 1087 monkeys had normal stools.

The fecal specimens were collected from the floor by using sterile disposable polyethylene gloves prior to room cleaning, placed into 50-ml plastic centrifuge tubes and transported to the laboratory in coolers with ice packs. The specimens were stored in $2.5 \%$ potassium dichromate solution at $4{ }^{\circ} \mathrm{C}$ for less than two months prior to DNA extraction.

\section{DNA extraction}

About $200 \mathrm{mg}$ of each fecal specimen was washed three times with distilled water by centrifugation at $2000 \times g$ for $10 \mathrm{~min}$. Genomic DNA was isolated from the washed fecal material by using a FastDNA SPIN Kit for soil (MP Biomedicals, Santa Ana, CA, USA) and stored at $-20{ }^{\circ} \mathrm{C}$ before PCR analysis within one year.

\section{Cryptosporidium genotyping and subtyping}

Cryptosporidium was detected by nested PCR amplification of a $\sim 830$-bp fragment of the $18 S$ rRNA gene [13]. The species present was determined by sequence analysis of the PCR products. To subtype $C$. parvum and $C$. hominis, a $\sim 850$-bp fragment of the $60 \mathrm{kDa}$ glycoprotein $(g p 60)$ gene was analyzed by nested PCR and DNA sequencing [14]. Another set of gp60 primers targeting a $~ 1000$-bp fragment were used in subtyping Cryptosporidium ubiquitum [15]. Each specimen was analyzed by PCR at least twice, with Cryptosporidium bovis DNA being used as the positive control for the $18 S$ rRNA PCR and DNA of C. parvum IOWA isolate (Waterborne, Inc., New Orleans, LA, USA) as the positive control for the gp60 PCR. A negative control with reagent water was used in each PCR analysis.

\section{Sequence analysis}

All secondary PCR products of the $18 S$ rRNA and gp 60 genes were bi-directionally sequenced using the secondary PCR primers on an ABI 3730 Genetic Analyzer (Applied Biosystems, Foster City, CA, USA). Nucleotide sequences generated were assembled by using software ChromasPro v.1.32 (http://technelysium.com.au/Chrom asPro.html), aligned with reference sequences from GenBank by using ClustalX (http://clustal.org). A maximum likelihood (ML) tree was constructed by using MEGA6 
(https://www.megasoftware.net/). The robustness of the cluster formation was assessed by using bootstrapping with 1000 pseudo-replicates. Representative sequences generated in this study were submitted to the GenBank database under accession numbers MG952704MG952706, MG952708-MG952714 and MK509808. Alignments of the $18 \mathrm{~S}$ rRNA and gp60 sequences are presented as Additional file 1: Figure S1 and Additional file 2: Figure S2.

\section{Measurement of oocyst shedding intensity}

A quantitative PCR (qPCR), 18S-LC2 targeting the 185 rRNA gene but with the use of SYBR Green instead of FRET probes for detection, was used to estimate the intensity of oocyst shedding in Cryptosporidium-positive specimens [16]. The 20- $\mu \mathrm{l}$ qPCR mix consisted of $10 \mu \mathrm{l}$ of $2 \times$ SYBR Green Real-time PCR Master Mix (Toyobo Co., Ltd., Osaka, Japan), $0.8 \mu \mathrm{l}$ of $10 \mathrm{mg} / \mathrm{ml}$ bovine serum albumin, $1 \mu \mathrm{l}$ of $10 \mu \mathrm{M}$ primers (each), $1 \mu \mathrm{l}$ of DNA and $6.2 \mu \mathrm{l}$ of PCR grade water. The qPCR was conducted on a LightCycler 480 II (Roche, Indianapolis, IN, USA) as follows: 1 cycle at $95^{\circ} \mathrm{C}$ for $3 \mathrm{~min} ; 50$ cycles at $95^{\circ} \mathrm{C}$ for $5 \mathrm{~s}$, $55{ }^{\circ} \mathrm{C}$ for $10 \mathrm{~s}$ and $72{ }^{\circ} \mathrm{C}$ for $40 \mathrm{~s} ; 1$ cycle at $95{ }^{\circ} \mathrm{C}$ for $10 \mathrm{~s}$ and $50{ }^{\circ} \mathrm{C}$ for $30 \mathrm{~s}$, and $0.1{ }^{\circ} \mathrm{C}$ melt steps from 50 to $80^{\circ} \mathrm{C}$; and cooling at $40{ }^{\circ} \mathrm{C}$ for $30 \mathrm{~s}$. The $\mathrm{Ct}$ values generated in the qPCR were used in estimating the number of oocysts per gram of feces (OPG) in Cryptosporidium-positive specimens, using a standard curve generated with negative fecal specimens spiked with $10^{2}, 10^{3}, 10^{4}, 10^{5}$ and $10^{6}$ oocysts of the C. parvum IOWA isolate.

\section{Statistical analysis}

The Chi-square test implemented in SPSS Statistics v.20.0 for Windows (SPSS, Inc., Chicago, IL, USA) was used to compare differences in Cryptosporidium prevalence between gender, age groups or animals with and without diarrhea. Student's t-test was used to compare average OPG between Cryptosporidium species or subtype families. Differences with $P<0.05$ were considered significant.

\section{Results}

Occurrence of Cryptosporidium in crab-eating macaques A total of 132 specimens (9.1\%) were positive for Cryptosporidium among the 1452 fecal specimens from crabeating macaques. The prevalence of Cryptosporidium in the first batch of specimens $(1.3 \%, 3 / 236)$ was significantly lower than that of the second $(13.3 \%, 53 / 399$; $\left.x^{2}=26.61, \quad d f=1, \quad P<0.0001\right)$, third $(10.9 \%, 64 / 586$; $\left.X^{2}=20.93, d f=1, P<0.0001\right)$ or fourth batch of specimens $\left(5.2 \%, 12 / 231 ; \chi^{2}=5.78, d f=1, P=0.0162\right)$ (Table 1$)$.

By sex, the prevalence of Cryptosporidium in females was significantly higher than in males $\left(\chi^{2}=16.16, d f=1\right.$, $P=0.0001$; Table 2). By age, the prevalence in animals 1 -3-years-old was significantly higher than in animals above 3 -years-old $\left(\chi^{2}=14.46, d f=1, P=0.0001\right.$; Table 2$)$. By fecal consistency, the prevalence in animals with loose stools was significantly higher than in animals with normal stools $\left(\chi^{2}=7.28, d f=1, P=0.0070\right.$; Table 2$)$.

\section{Occurrence of Cryptosporidium species}

Based on sequence analysis of the $18 S$ rRNA PCR products, four Cryptosporidium species were identified among the 132 positive specimens. Among them, C. hominis was detected in 86 specimens, with $18 S \mathrm{rRNA}$ sequences identical to the reference KF679722 obtained from NHPs in China [10]. Compared with nucleotide sequences from most $C$. hominis isolates from humans, they had nine (instead of 11) consecutive $\mathrm{T}$ in the hypervariable

Table 1 Occurrence of Cryptosporidium species and subtypes in crab-eating macaques in Hainan, China

\begin{tabular}{|c|c|c|c|c|c|c|c|c|c|}
\hline \multirow[t]{2}{*}{ Sampling } & \multirow[t]{2}{*}{ Sample size } & \multirow{2}{*}{$\begin{array}{l}\text { No. positive for } \\
\text { Cryptosporidium } \\
(\%)\end{array}$} & \multicolumn{2}{|l|}{ C.parvum } & \multicolumn{2}{|l|}{ C.hominis } & \multicolumn{2}{|l|}{ C. ubiquitum } & \multirow{2}{*}{$\begin{array}{l}\text { C.muris } \\
\text { No. positive }\end{array}$} \\
\hline & & & No. positive & Subtype $(n)$ & No. positive & Subtype $(n)$ & No. positive & Subtype (n) & \\
\hline 1st (Apr. 2016) & 236 & $3(1.3)$ & - & - & 1 & - & - & - & 2 \\
\hline 2nd (Jun. 2017) & 399 & $53(13.3)$ & 14 & IIoA14G1 (9) & 32 & $\begin{array}{l}\operatorname{ImA18}(12) ; \\
\ln A 14(6) ; \\
\operatorname{liA} 17(1)\end{array}$ & 1 & XIId (1) & 6 \\
\hline 3rd (Oct. 2017) & 586 & $64(10.9)$ & 15 & $\begin{array}{l}\text { IoA14G1 (9); } \\
\text { IIdA19G1 (2), }\end{array}$ & 49 & $\begin{array}{l}\operatorname{ImA18}(26) \\
\ln A 26(5) ; \\
\ln A 17(1) \\
\ln (1)\end{array}$ & - & - & - \\
\hline 4th (Jan. 2018) & 231 & $12(5.2)$ & 1 & - & 4 & $\begin{array}{l}\ln A 26(1) ; \mid \text { liA17 } \\
(2)\end{array}$ & - & - & 7 \\
\hline Total & 1452 & $132(9.1)$ & 30 & $\begin{array}{r}\text { IoA14G1 (18); } \\
\text { IIdA19G1 (2) }\end{array}$ & 86 & $\begin{array}{l}\operatorname{ImA18}(38) \\
\text { In (1); InA14 } \\
(6) ; \operatorname{InA} 17(1) ; \\
\text { InA26 (6); } \\
\operatorname{liA} 17(3)\end{array}$ & 1 & XIId (1) & 15 \\
\hline
\end{tabular}


Table 2 Cryptosporidium species and subtypes in crab-eating macaques in Hainan, China by age, sex and fecal consistency

\begin{tabular}{|c|c|c|c|c|c|c|c|c|c|}
\hline \multirow[t]{2}{*}{ Specimen } & \multirow[t]{2}{*}{ Sampling size } & \multirow{2}{*}{$\begin{array}{l}\text { No. positive for } \\
\text { Cryptosporidium } \\
\text { (\%) }\end{array}$} & \multicolumn{4}{|c|}{ Cryptosporidium species } & \multirow{2}{*}{$\begin{array}{l}\text { C. parvum } \\
\text { subtype (n) }\end{array}$} & \multirow{2}{*}{$\begin{array}{l}\text { C. hominis } \\
\text { subtype (n) }\end{array}$} & \multirow{2}{*}{$\begin{array}{l}\text { C. ubiquitum } \\
\text { subtype ( } n \text { ) }\end{array}$} \\
\hline & & & $\begin{array}{l}\text { No. of } C \text {. } \\
\text { parvum }\end{array}$ & $\begin{array}{l}\text { No. of } C \text {. } \\
\text { hominis }\end{array}$ & No. of C. muris & $\begin{array}{l}\text { No. of } C \text {. } \\
\text { ubiquitum }\end{array}$ & & & \\
\hline 1-2-years-old & 609 & $71(11.7)$ & 21 & 47 & 3 & - & $\begin{array}{l}\text { IloA14G1 (14); } \\
\text { IIdA19G1 (1) }\end{array}$ & $\begin{array}{l}\operatorname{ImA18}(26) \\
\operatorname{InA17}(1) ; \operatorname{In}(1) \\
\ln A 26(4)\end{array}$ & - \\
\hline 2-3-years-old & 493 & $47(9.5)$ & 9 & 30 & 7 & 1 & $\begin{array}{l}\text { IIdA19G1 (1); } \\
\quad \text { |loA14G1 (4) }\end{array}$ & $\begin{array}{l}\operatorname{ImA18}(12) \\
\operatorname{InA} \mathrm{14}(6)\end{array}$ & XIId (1) \\
\hline >3-years-old & 350 & $14(4.0)^{\mathrm{a}}$ & - & 9 & 5 & - & - & $\begin{array}{l}\operatorname{liA} 17 \text { (3); InA26 } \\
\quad(2)\end{array}$ & - \\
\hline Male & 706 & $43(6.1)$ & 17 & 13 & 12 & 1 & $\begin{array}{l}\text { IloA14G1 (12); } \\
\text { IdA19G1 (1) }\end{array}$ & $\ln A 26(3)$ & XIId (1) \\
\hline Female & 599 & $75(12.5)^{b}$ & 6 & 68 & 1 & - & $\begin{array}{l}\text { IIoA14G1 (1); } \\
\text { IIdA19G1 (1) }\end{array}$ & $\begin{array}{l}\text { ImA18 (38); In (1); } \\
\text { InA14 (6); InA17 } \\
\text { (1); InA26 (3); } \\
\text { liA17 (2) }\end{array}$ & - \\
\hline Unknown sex & 147 & $14(11.6)$ & 4 & 2 & & & IloA14G1 (5) & liA17 (1) & - \\
\hline Normal stools & 1087 & $86(7.9)$ & 20 & 50 & 15 & 1 & $\begin{array}{l}\text { IoA14G1 (12); } \\
\text { IIdA19G1 (1) }\end{array}$ & $\begin{array}{l}\text { ImA18 (13); } \\
\text { InA14 (6); IiA17 } \\
\text { (3); In (1); InA17 } \\
\text { (1); InA26 (4) }\end{array}$ & XIId (1) \\
\hline Loose stools & 365 & $46(12.6)^{c}$ & 10 & 36 & - & - & $\begin{array}{l}\text { IoA14G1 (6); } \\
\text { IIAA19G1 (1) }\end{array}$ & $\begin{array}{l}\operatorname{ImA18}(25) \\
\operatorname{InA26(2)}\end{array}$ & - \\
\hline Total & 1452 & $132(9.1)$ & 30 & 86 & 15 & 1 & $\begin{array}{l}\text { IoA14G1 (18); } \\
\text { IIdA19G1 (2) }\end{array}$ & $\begin{array}{l}\text { ImA18 (38); In (1); } \\
\text { InA14 (6); InA17 } \\
\text { (1); InA26 (6); } \\
\text { liA17 (3) }\end{array}$ & XIId (1) \\
\hline
\end{tabular}

\footnotetext{
a $P<0.05$, for above 3-years-old in comparison with 1-3-years-old

b $P<0.05$, for females in comparison with male monkeys

c $P<0.05$, for loose stools in comparison with normal stools
}

region of the gene and an $\mathrm{A}$ to $\mathrm{T}$ substitution upstream from it. In contrast, C. parvum was detected in 30 specimens, with nucleotide sequences identical to the reference MF074701 obtained from dairy calves in China [17]. Between the remaining two Cryptosporidium species, $C$. muris was identified in 15 specimens while $C$. ubiquitum in one specimen, producing $18 S$ rRNA sequences that were identical to KF419208 obtained from brown rats in China and KT027449 obtained from eastern gray squirrels in the USA, respectively $[18,19]$.

\section{Occurrence of $C$. parvum, C. hominis and C. ubiquitum subtypes}

Among the 117 specimens that were positive for $C$. parvum-, C. hominis- and C. ubiquitum-positive specimens, 76 were successfully subtyped at the gp60 locus, namely 20 of the 30 C. parvum-positive specimens, 55 of the 86 C. hominis-positive specimens and the only C. ubiquitum-positive specimen (Table 1 ). The remaining 15 specimens that were positive for $C$. muris did not produce the expected gp60 PCR products.

Two known subtypes were identified among C. par$v u m$-positive specimens, namely IIoA14G1 (18/20) and
IIdA19G1 (2/20), with nucleotide sequences identical to the reference sequence KC885906 and KJ802724, respectively $[20,21]$.

Six subtypes were identified within $C$. hominis: one subtype of a new subtype family Im; four subtypes of a new subtype family In; and one subtype of the known subtype family Ii. The new subtype family Im had a nucleotide sequence that was very similar to the Ia family (GenBank: AF164502), with 15 (2\%) nucleotide substitutions in the non-repeat region. Only one subtype, ImA18, was present within the subtype family, and was seen in 38 specimens. In contrast, the new family In had nucleotide sequences that were similar to the Id family (GenBank: GU214353), with 28 (3\%) nucleotide substitutions in the non-repeat region. It included subtypes InA14, InA17 and InA26, which were detected in 6, 1 and 6 specimens, respectively. One sequence from the In subtype family had un-readable trinucleotide region. As expected, in phylogenetic analysis, Im and In clustered with Ia and Id subtype families, respectively (Fig. 1). The IiA17 subtype in the Ii subtype family had a nucleotide sequence identical to KF679724 [10], and was detected in 3 specimens. 


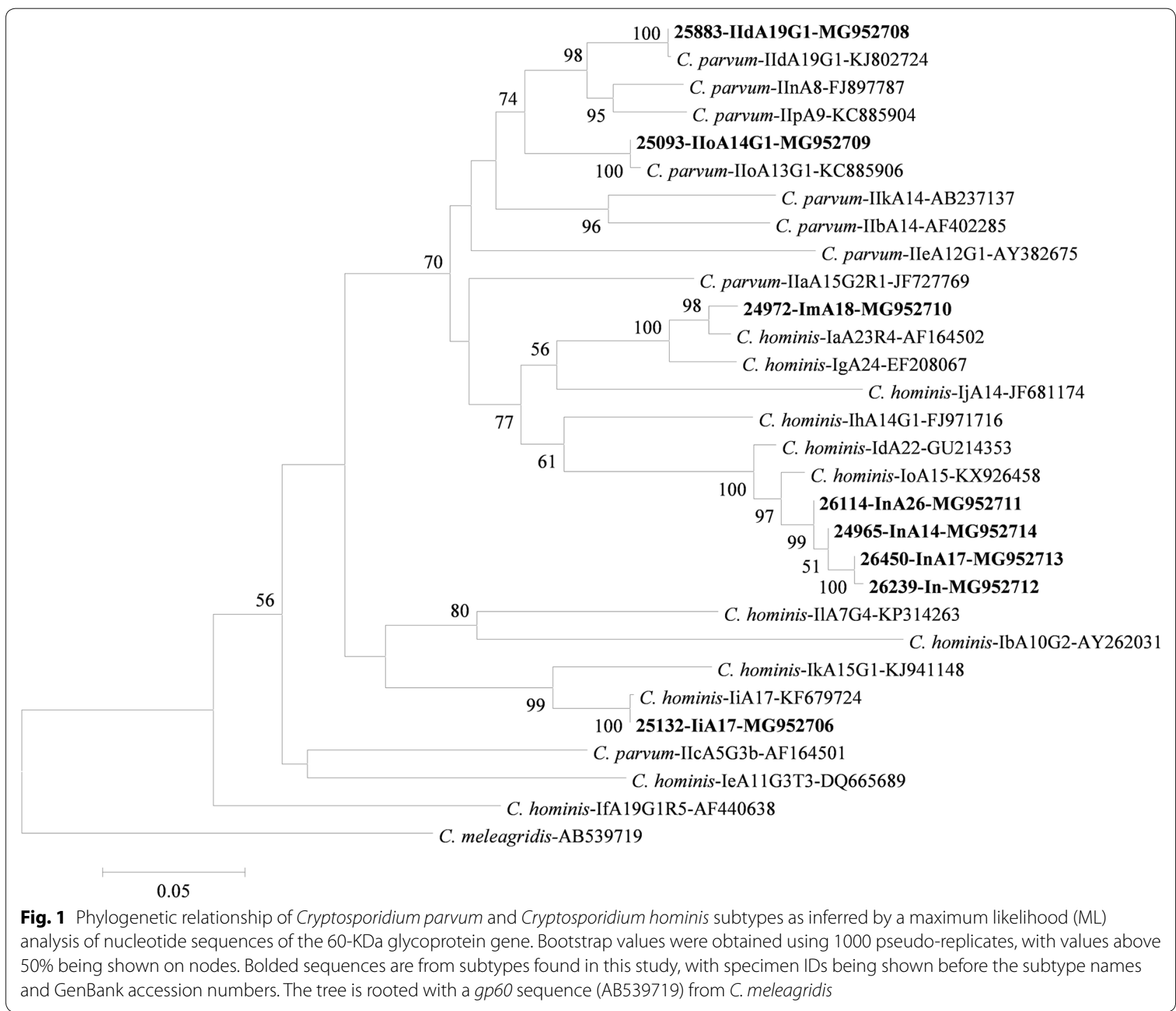

The only $C$. ubiquitum specimen was subtyped as XIId, with a nucleotide sequence identical to the reference sequence JX412924, which was seen in rodents and humans in the USA [15].

\section{Occurrence of Cryptosporidium subtypes by sampling date,} gender, age and fecal consistency

The two common subtypes ImA18 (38/55) and IIoA14G1 (18/20) were only found at the second and third sampling (Table 1). Subtype ImA18 was only detected in females (38/53), while IIoA14G1 was the dominant subtype in males (12/17). By age, these two subtypes were almost exclusively found in 1-3-year-old animals. By fecal consistency, ImA18 was more likely detected in animals with loose stools than animals with normal stools $\left(\chi^{2}=13.62, d f=1, P=0.000\right)$. IIoA14G1, on the other hand, was detected in animals with the two types of fecal consistency at similar frequency (6/34 vs $12 / 42)$. Other subtypes in this study were mostly found in animals with normal stools (Table 2).

\section{Oocyst shedding intensity of different Cryptosporidium species and $C$. hominis subtypes}

By species, the average number of oocysts per gram of feces (OPG) of 65 C. hominis-positive specimens was 2462 , which was higher than that of 27 C. parvumpositive specimens $\left(805 ; t_{(90)}=1.05, P=0.296\right), 13 C$. muris-positive specimens $\left(578 ; t_{(76)}=1.77, P=0.081\right)$ and the only $C$. ubiquitum-positive specimen (65). By C. hominis subtype, the average OPG of $32 \mathrm{Im}$-positive specimens was higher than that of 12 In-positive specimens $\left(t_{(42)}=1.93, P=0.063\right)$ (Fig. 2). 


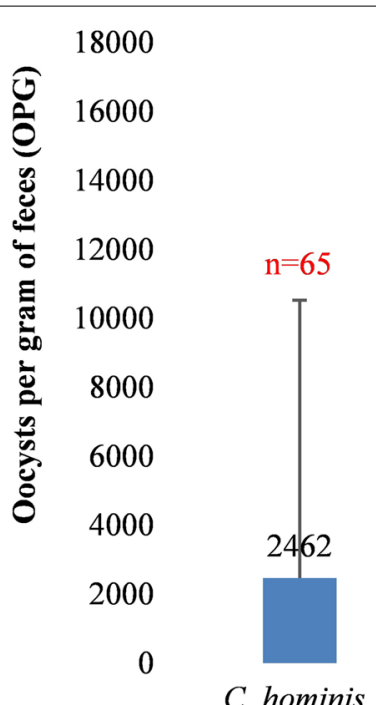

C. hominis

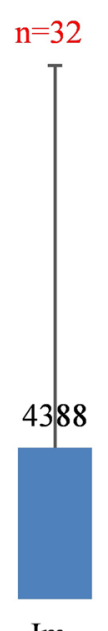

Im

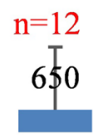

In

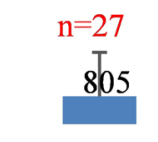

C. parvum

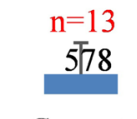

C. muris

\section{Species of Cryptosporidium and subtype families of $\boldsymbol{C}$. hominis}

Fig. 2 Oocysts per gram of feces in specimens of dominant Cryptosporidium species and Cryptosporidium hominis subtypes in crab-eating macaques in Hainan, China. The sample size $(n)$ for each species or subtype is specified above the bar. None of the differences reached statistical significance $(P>0.05)$

\section{Discussion}

In this study, Cryptosporidium was commonly found in crab-eating macaques on a large commercial farm. The 9.1\% (132/1452) prevalence is higher than the prevalence reported in NHPs in Shaanxi $(7.0 \%, 6 / 86)$, Anhui $(2.3 \%$, $1 / 44)$, Guangxi $(0.5 \%, 1 / 205)$ and southern provinces $(0.7 \%, 19 / 2660)$ of China $[8,10,11,22]$. However, it is similar to the prevalence in free-range rhesus monkeys in a public park in Guizhou $(10.9 \%, 45 / 411)$ [7]. Elsewhere in the world, it is higher than the prevalence of NHPs found in Uganda $(6.7 \%, 10 / 149)$, Rwanda $(4.0 \%, 4 / 100)$, Madagascar $(4.0 \%, 1 / 25)$, Kenya $(2.6 \%, 6 / 235)$ and Thailand $(1.0 \%, 2 / 200)$ [23-28], but slightly lower than the prevalence in Tanzania $(16.0 \%, 21 / 131)$ [9].

A diverse range of Cryptosporidium species were identified in crab-eating macaques in the present study, namely C. hominis (in 86 animals), C. parvum (in 30 animals), C. muris (in 15 animals) and C. ubiquitum (in one animal). Similarly, studies conducted prior to the present study had identified nine Cryptosporidium species in a total of 163 Cryptosporidium-positive fecal specimens from NHPs, namely C. hominis $(50.3 \%, 82 / 163)$, C. muris (21.5\%, 35/163), C. parvum (16.0\%, 26/163), C. suis $(3.7 \%, 6 / 163)$, C. andersoni $(3.1 \%, 5 / 163)$, C. ubiquitum $(3.1 \%, 5 / 163)$, C. meleagridis $(1.2 \%, 2 / 163), C$. bovis $(0.6 \%, 1 / 163)$ and C. felis $(0.6 \%, 1 / 163)[4,6-11,15,22-$ $38]$. Nevertheless, the frequency $(30 / 132$ or $22.7 \%)$ of the zoonotic C. parvum in crab-eating macaques in the present study is much higher than in previous studies.
Previously, most $C$. parvum infections were found in NHPs in Uganda and China [7, 8, 22, 27, 28, 33, 36, 37, 39]. The large number of $C$. muris infections $(15 / 132)$ in this study support previous observation of this zoonotic species in NHPs elsewhere [4, 10, 22, 24, 38, 40].

The C. parvum subtypes found in this study appear to be unique. Previously, C. parvum reported in NHPs belonged to the common subtype families IIc and IId $[7,8]$. However, in this study, the rare subtype family IIo was detected in NHPs for the first time. Compared with common C. parvum subtype families, the Ilo subtype family has two nucleotide substitutions in the $18 \mathrm{~S}$ rRNA gene. Two subtypes of this subtype family, IIoA16G1 and IIoA13G1, were detected in humans traveling to Thailand as well as bamboo rats in China [20, 41, 42]. The large number of IIoA14G1 infections in this study indicates that the zoonotic subtype family has expanded its range from rodents to NHPs in southern China. In contrast, the IIdA19G1 subtype found in a few monkeys is one of the two common IId subtypes infecting ruminants and rodents in China [17, 43-48]. The detection of both IIoA14G1 and IIdA19G1 in this study supports the previous conclusion that rodents are important reservoirs of C. parvum in China, and suggests that the rodents might play an important role in the transmission of these pathogens in NHPs [5].

Similarly, C. hominis detected in this study belongs to highly divergent subtype families. Most of $C$. hominis isolates detected belong to two new subtype families Im and 
In, while the remaining ones belong to the NHP-adapted subtype family Ii. The sequence differences between Im and Ia (15 nucleotides) or In and Id (28 nucleotides) are greater than those between IIe and IIm, which differ from each other by 13 nucleotides in the non-repeat region. In previous studies, human-pathogenic subtype families Ia, Ib, Id, Ie and If were commonly detected in NHPs [7, 9, $10,22,23]$. The Im and In detected in this study appear to be genetically divergent from them, as they also differ from them by two nucleotides at the $18 \mathrm{~S}$ rRNA locus. Among them, the In subtype family was previously seen in a farmed crab-eating macaque in Guangxi, although it was mistakenly named as IdA14 [11]. Similarly, IiA17 of the Ii subtype family has the same sequence variations at the $18 S$ rRNA gene and had been detected in only a few NHPs $[5,10,49]$. The IiA14 detected in one baboon in Kenya previously [23] was actually IjA14 (JF681174) [50]. As Ii subtype family has been found in some human cases, it is apparently zoonotic $[5,51]$.

There were apparent differences in the transmission of the two common subtypes of C. parvum and C. hominis, IIoA14G1 and ImA18. By sex, ImA18 was only found in females, while IIoA14G1 was the major subtype in males (Table 2). However, this could be due to the fact that females and males were kept in different areas in the facility. By fecal consistency, ImA18 and IIoA14G1 were overrepresented in animals with loose stools (in 31/34 subtyped specimens from animals with loose stool, compared with in 25/41 subtyped specimens from animals with normal stools), while other subtypes were mainly found in animals with normal stools (Table 2). In addition, the number of monkeys infected with $C$. hominis $(n=86)$ was higher than those infected with $C$. parvum $(n=30)$ and $C$. muris $(n=15)$. Among them, C. hominis had higher oocyst shedding intensity than C. parvum and C. muris, while within the former, the Im subtype family had higher oocyst shedding intensity than the In subtype family $(P>0.05$, Fig. 2$)$. Differences in oocyst shedding indicate that virulence is associated to the type of species and subtypes infecting NHPs.

\section{Conclusions}

In conclusion, diverse Cryptosporidium species and subtypes are present in farmed crab-eating macaques in Hainan, China. The C. hominis subtype families (Im, In and Ii) appear to be NHP-adapted, while C. parvum subtype family IIo appears to have expanded its host range. More studies should be conducted in other regions to monitor the dispersal of these divergent $C$. parvum and C. hominis subtypes. Comparative genomic analysis should be conducted to further understand their genetic uniqueness.

\section{Additional files}

Additional file 1: Figure S1. Alignment of nucleotide sequences of the 185 rRNA gene of Cryptosporidium species.

Additional file 2: Figure S2. Alignment of nucleotide sequences of the $60 \mathrm{kDa}$ glycoprotein gene of Cryptosporidium parvum and Cryptosporidium hominis.

Abbreviations

PCR: polymerase chain reaction; qPCR: quantitative PCR; NHPs: non-human primates; gp60: 60 kDa glycoprotein gene; OPG: oocysts per gram of feces.

\section{Acknowledgements}

We thank the farm owner and staff for their assistance in sample collection during this study.

\section{Authors' contributions}

YF and LX conceived and designed the experiments; LC, SH and WJ performed the experiments; LC, SH, JZ, WJ, CL, NL, YG and QH analyzed the data; LC, YF and LX wrote the paper. All authors read and approved the final manuscript.

\section{Funding}

This work was supported by the National Natural Science Foundation of China (31820103014, 31630078, and 31602042).

\section{Availability of data and materials}

The data supporting the conclusions of this article are included within the article and its additional files. Representative sequences generated in this study were submitted to the GenBank database under accession numbers MG952704-MG952706, MG952708-MG952714 and MK509808.

\section{Ethics approval and consent to participate}

This study was approved by the Research Ethics Committee of the East China University of Science and Technology (2015018). Permission for collecting fecal specimens was obtained from the manager of the farm. Animals were handled according to the Animal Ethics Procedures and Guidelines of the People's Republic of China.

\section{Consent for publication}

Not applicable.

\section{Competing interests}

The authors declare that they have no competing interests.

\section{Author details}

1 State Key Laboratory of Bioreactor Engineering, School of Resource and Environmental, East China University of Science and Technology, Shanghai 200237, China. ${ }^{2}$ College of Veterinary Medicine, South China Agricultural University, Guangzhou 510642, China. ${ }^{3}$ Key Laboratory of Tropical Biological Resources of Ministry of Education, School of Life and Pharmaceutical Sciences, Hainan University, Haikou 570228, Hainan, China.

Received: 6 May 2019 Accepted: 6 July 2019

Published online: 15 July 2019

\section{References}

1. Checkley W, White AC Jr, Jaganath D, Arrowood MJ, Chalmers RM, Chen $X M$, et al. A review of the global burden, novel diagnostics, therapeutics, and vaccine targets for Cryptosporidium. Lancet Infect Dis. 2015;15:85-94.

2. Santin M. Clinical and subclinical infections with Cryptosporidium in animals. N Z Vet J. 2013;61:1-10.

3. Xiao L. Molecular epidemiology of cryptosporidiosis: an update. Exp Parasitol. 2010;124:80-9.

4. Li J, Dong H, Wang R, Yu F, Wu Y, Chang Y, et al. An investigation of parasitic infections and review of molecular characterization of the intestinal 
protozoa in nonhuman primates in China from 2009 to 2015. Int J Parasitol Parasites Wildl. 2017;6:8-15.

5. Feng Y, Ryan UM, Xiao L. Genetic diversity and population structure of Cryptosporidium. Trends Parasitol. 2018;34:997-1011.

6. Feng Y, Xiao L. Molecular epidemiology of cryptosporidiosis in China. Front Microbiol. 2017;8:1701.

7. Ye J, Xiao L, Ma J, Guo M, Liu L, Feng Y. Anthroponotic enteric parasites in monkeys in public park, China. Emerg Infect Dis. 2012;18:1640-3.

8. Du S, Zhao G, Shao J, Fang Y, Tian G, Zhang L, et al. Cryptosporidium spp., Giardia intestinalis, and Enterocytozoon bieneusi in captive non-human primates in Qinling Mountains. Korean J Parasitol. 2015;53:395-402.

9. Parsons MB, Travis D, Lonsdorf EV, Lipende I, Roellig DM, Collins A, et al. Epidemiology and molecular characterization of Cryptosporidium spp. in humans, wild primates, and domesticated animals in the Greater Gombe Ecosystem, Tanzania. PLoS NegI Trop Dis. 2015;9:e0003529.

10. Karim MR, Zhang S, Jian F, Li J, Zhou C, Zhang L, et al. Multilocus typing of Cryptosporidium spp. and Giardia duodenalis from non-human primates in China. Int J Parasitol. 2014;44:1039-47.

11. Ye J, Xiao L, Li J, Huang W, Amer SE, Guo Y, et al. Occurrence of humanpathogenic Enterocytozoon bieneusi, Giardia duodenalis and Cryptosporidium genotypes in laboratory macaques in Guangxi, China. Parasitol Int. 2014:63:132-7.

12. Zhao W, Zhou H, Jin H, Liu M, Qiu M, Li L, et al. Molecular prevalence and subtyping of Cryptosporidium hominis among captive long-tailed macaques (Macaca fascicularis) and rhesus macaques (Macaca mulatta) from Hainan Island, southern China. Parasit Vectors. 2019;12:192.

13. Jiang J, Alderisio KA, Singh A, Xiao L. Development of procedures for direct extraction of Cryptosporidium DNA from water concentrates and for relief of PCR inhibitors. Appl Environ Microbiol. 2005;71:1135-41.

14. Feng Y, Li N, Duan L, Xiao L. Cryptosporidium genotype and subtype distribution in raw wastewater in Shanghai, China: evidence for possible unique Cryptosporidium hominis transmission. J Clin Microbiol. 2009:47:153-7.

15. Li N, Xiao L, Alderisio K, Elwin K, Cebelinski E, Chalmers R, et al. Subtyping Cryptosporidium ubiquitum, a zoonotic pathogen emerging in humans. Emerg Infect Dis. 2014;20:217-24.

16. Li N, Neumann NF, Ruecker N, Alderisio KA, Sturbaum GD, Villegas EN, et al. Development and evaluation of three real-time PCR assays for genotyping and source tracking Cryptosporidium spp. in water. Appl Environ Microbiol. 2015;81:5845-54.

17. Cai M, Guo Y, Pan B, Li N, Wang X, Tang C, et al. Longitudinal monitoring of Cryptosporidium species in pre-weaned dairy calves on five farms in Shanghai, China. Vet Parasitol. 2017;241:14-9.

18. Liu X, He T, Zhong Z, Zhang H, Wang R, Dong $H$, et al. A new genotype of Cryptosporidium from giant panda (Ailuropoda melanoleuca) in China. Parasitol Int. 2013;62:454-8.

19. Stenger BLS, Clark ME, Kvac M, Khan E, Giddings CW, Prediger J, McEvoy JM. North American tree squirrels and ground squirrels with overlapping ranges host different Cryptosporidium species and genotypes. Infect Genet Evol. 2015;36:287-93.

20. Liu X, Zhou X, Zhong Z, Zuo Z, Shi J, Wang Y, et al. Occurrence of novel and rare subtype families of Cryptosporidium in bamboo rats (Rhizomys sinensis) in China. Vet Parasitol. 2015;207:144-8.

21. Waldron LS, Power ML. Fluorescence analysis detects gp60 subtype diversity in Cryptosporidium infections. Infect Genet Evol. 2011;11:1388-95.

22. Gu Y, Wang X, Zhou C, Li P, Xu Q, Zhao C, et al. Investigation on Cryptosporidium infections in wild animals in a zoo in Anhui Province. J Zoo Wildl Med. 2016;47:846-54

23. Li W, Kiulia NM, Mwenda JM, Nyachieo A, Taylor MB, Zhang X, Xiao L. Cyclospora papionis, Cryptosporidium hominis, and human-pathogenic Enterocytozoon bieneusi in captive baboons in Kenya. J Clin Microbiol. 2011;49:4326-9.

24. Sak B, Petrzelkova KJ, Kvetonova D, Mynarova A, Pomajbikova K, Modry D, et al. Diversity of microsporidia, Cryptosporidium and Giardia in mountain gorillas (Gorilla beringei beringei) in Volcanoes National Park, Rwanda. PLoS One. 2014;9:e109751.

25. Sricharern W, Inpankaew T, Keawmongkol S, Supanam J, Stich RW, Jittapalapong S. Molecular detection and prevalence of Giardia duodenalis and Cryptosporidium spp. among long-tailed macaques (Macaca fascicularis) in Thailand. Infect Genet Evol. 2016;40:310-4.
26. Bodager JR, Parsons MB, Wright PC, Rasambainarivo F, Roellig D, Xiao L, Gillespie TR. Complex epidemiology and zoonotic potential for Cryptosporidium suis in rural Madagascar. Vet Parasitol. 2015;207:140-3.

27. Nolan MJ, Unger M, Yeap YT, Rogers E, Millet I, Harman K, et al. Molecular characterisation of protist parasites in human-habituated mountain gorillas (Gorilla beringei beringei), humans and livestock, from Bwindi Impenetrable National Park, Uganda. Parasit Vectors. 2017;10:340.

28. Salyer SJ, Gillespie TR, Rwego IB, Chapman CA, Goldberg TL. Epidemiology an molecular relationships of Cryptosporidium spp. in people, primates, and livestock from Western Uganda. PLoS Neglec Trop Dis. 2012;6:e1597.

29. Xiao L, Fayer R. Molecular characterisation of species and genotypes of Cryptosporidium and Giardia and assessment of zoonotic transmission. Int J Parasitol. 2008:38:1239-55.

30. Fayer R, Santin M, Macarisin D. Cryptosporidium ubiquitum n. sp. in animals and humans. Vet Parasitol. 2010;172:23-32.

31. Feng Y. Cryptosporidium in wild placental mammals. Exp Parasitol. 2010;124:128-37.

32. Liu X, Xie N, Li W, Zhou Z, Zhong Z, Shen L, et al. Emergence of Cryptosporidium hominis monkey genotype II and novel subtype family lk in the squirrel monkey (Saimiri sciureus) in China. PLoS ONE. 2015;10:e0141450.

33. Graczyk TK, DaSilva AJ, Cranfield MR, Nizeyi JB, Kalema GR, Pieniazek NJ. Cryptosporidium parvum genotype 2 infections in free-ranging mountain gorillas (Gorilla gorilla beringei) of the Bwindi Impenetrable National Park, Uganda. Parasitol Res. 2001;87:368-70.

34. Nizeyi JB, Sebunya D, Dasilva AJ, Cranfield MR, Pieniazek NJ, Graczyk TK. Cryptosporidiosis in people sharing habitats with free-ranging mountain gorillas (Gorilla gorilla beringei), Uganda. Am J Trop Med Hyg. 2002;66:442-4.

35. Sak B, Petrzelkova KJ, Kvetonova D, Mynarova A, Shutt KA, Pomajbikova $\mathrm{K}$, et al. Long-term monitoring of microsporidia, Cryptosporidium and Giardia infections in western Lowland Gorillas (Gorilla gorilla gorilla) at different stages of habituation in Dzanga Sangha Protected Areas, Central African Republic. PLoS ONE. 2013;8:e71840.

36. Da SA, Cacciò S, Williams C, Won KY, Nace EK, Whittier C, et al. Molecular and morphologic characterization of a Cryptosporidium genotype identified in lemurs. Vet Parasitol. 2003;111:297-307.

37. Ekanayake DK, Welch DM, Kieft R, Hajduk S, Dittus WP. Transmission dynamics of Cryptosporidium infection in a natural population of non-human primates at Polonnaruwa, Sri Lanka. Am J Trop Med Hyg. 2007;77:818-22.

38. Dubey JP, Markovits JE, Killary KA. Cryptosporidium muris-like infection in stomach of cynomolgus monkeys (Macaca fascicularis). Vet Pathol. 2002;39:363-71.

39. Nizeyi JB, Mwebe R, Nanteza A, Cranfield MR, Kalema GR, Graczyk TK. Cryptosporidium sp. and Giardia sp. infections in mountain gorillas (Gorilla gorilla beringei) of the Bwindi Impenetrable National Park, Uganda. J Parasitol. 1999;85:1084-8.

40. Warren KS, Swan RA, Morgan-Ryan UM, Friend JA, Elliot A. Cryptosporidium muris infection in bilbies (Macrotis lagotis). Aust Vet J. 2003;81:739-41.

41. Insulander M, Silverlas C, Lebbad M, Karlsson L, Mattsson JG, Svenungsson B. Molecular epidemiology and clinical manifestations of human cryptosporidiosis in Sweden. Epidemiol Infect. 2013;141:1009-20.

42. Sannella AR, Suputtamongkol Y, Wongsawat E, Cacciò SM. A retrospective molecular study of Cryptosporidium species and genotypes in HIVinfected patients from Thailand. Parasit Vectors. 2019;12:91.

43. Lv C, Zhang L, Wang R, Jian F, Zhang S, Ning C, et al. Cryptosporidium spp. in wild, laboratory, and pet rodents in China: prevalence and molecular characterization. Appl Environ Microbiol. 2009;75:7692-9.

44. Mi R, Wang $X$, Huang Y, Zhou P, Liu Y, Chen Y, et al. Prevalence and molecular characterization of Cryptosporidium in goats across four provincial level areas in China. PLoS One. 2014;9:e111164.

45. Qi M, Cai J, Wang R, Li J, Jian F, Huang J, et al. Molecular characterization of Cryptosporidium spp. and Giardia duodenalis from yaks in the central western region of China. BMC Microbiol. 2015;15:108.

46. Zhao G, Du S, Wang H, Hu X, Deng M, Yu S, et al. First report of zoonotic Cryptosporidium spp., Giardia intestinalis and Enterocytozoon bieneusi in golden takins (Budorcas taxicolor bedfordi). Infect Genet Evol. 2015;34:394-401. 
47. Jian F, Liu A, Wang R, Zhang S, Qi M, Zhao W, et al. Common occurrence of Cryptosporidium hominis in horses and donkeys. Infect Genet Evol. 2016:43:261-6.

48. Peng X, Tian G, Ren G, Yu Z, Lok JB, Zhang L, et al. Infection rate of Giardia duodenalis, Cryptosporidium spp. and Enterocytozoon bieneusi in cashmere, dairy and meat goats in China. Infect Genet Evol. 2016;41:26-31.

49. Feng Y, Lal AA, Li N, Xiao L. Subtypes of Cryptosporidium spp. in mice and other small mammals. Exp Parasitol. 2011;127:238-42.

50. Xiao L, Feng Y. Molecular epidemiologic tools for waterborne pathogens Cryptosporidium spp. and Giardia duodenalis. Food Waterborne Parasitol. 2018;8-9:14-32.
51. Lebbad M, Winiecka-Krusnell J, Insulander M, Beser J. Molecular characterization and epidemiological investigation of Cryptosporidium hominis IkA18G1 and C. hominis monkey genotype liA17, two unusual subtypes diagnosed in Swedish patients. Exp Parasitol. 2018;188:50-7.

\section{Publisher's Note}

Springer Nature remains neutral with regard to jurisdictional claims in published maps and institutional affiliations.
Ready to submit your research? Choose BMC and benefit from:

- fast, convenient online submission

- thorough peer review by experienced researchers in your field

- rapid publication on acceptance

- support for research data, including large and complex data types

- gold Open Access which fosters wider collaboration and increased citations

- maximum visibility for your research: over 100M website views per year

At BMC, research is always in progress.

Learn more biomedcentral.com/submissions 